Bartın Üniversitesi

Eğitim Fakültesi Dergisi

Cilt 6, Sayı 1, s. 365-384, Subat 2017

BARTIN - TÜRKIYE

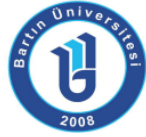

ISSN: 1308-7177
Bartin University

Journal of Faculty of Education

Volume 6, Issue 1, p. 365-384, February 2017

BARTIN - TURKEY

\title{
Romantic Relationship Satisfaction Levels of Female University Students in Turkey: Examining through Attachment Dimensions, Perceived Abuse in Relationship and Future Time Orientation of Relationship
}

\author{
Aylin DEMIRLI YILDIZ, Yrd. Doç. Dr., Başkent Üniversitesi Eğitim Fakültesi, adyildiz@baskent.edu.tr \\ Gökçe ÇOKAMAY, Arş. Gör., Ankara Üniversitesi Eğitim Bilimleri Fakültesi, gokcecokamay@gmail.com \\ Müge ARTAR, Prof. Dr., Ankara Üniversitesi Eğitim Bilimleri Fakültesi, mgeartar@gmail.com
}

\begin{abstract}
The study mainly aimed to identify an important task of emerging adulthood i.e. romantic relationships by investigating possible roles of socio-economic status of families, attachment dimensions, future orientation and perceived abuse in relations on relationship satisfaction of female university students. In this context, it is aimed to understand the role of being a student of state or private universities, as well as grades, relationship durations, family income, mothers' and fathers' education level and marital status of parents' among perceived abuse in relationship and satisfaction in relationship. To that end, we carried out the research in two different universities whose students have different socio-economic background with the assumption that it has an important role in perceiving abuse as well as in determining the value of romantic relationship. According to findings, students of the private university have more satisfaction in their romantic relationships than students of the state university. Females who are at higher-grades and have relatively longer relationship also have more relationship satisfaction. Besides, according to findings of regression analysis, predictive factors of romantic relationship satisfaction in sequence are avoidance attachment, perceived abuse in romantic relationship, anxiety attachment and future time orientation in romantic relationship.
\end{abstract}

Key Words: attachment dimensions, abuse in romantic relationship, abuse, relationship satisfaction, future orientation.

\section{Kadın Üniversite Öğrencilerinin Romantik İlişki Doyumunun Bağlanma Boyutları, iliş̧kide Algıladıkları İstismar ve Gelecek Zaman Yönetimi Açısından İncelenmesi}

Öz: Araştırmanın temel amacı beliren yetişkinlik döneminin en önemli gelişimsel görevlerinden biri olarak romantik ilişkileri araştırmaktır. Bu bağlamda ailelerin sosyo-ekonomik düzeylerinin, bağlanma boyutlarının, gelecek yöneliminin ve ilişkilerinde algıladıkları istismarın kadın üniversite öğrencilerinin ilişki doyumu ile ilişkisi incelenmiştir. Bu bağlamda, vakıf üniversitesinde okuyan öğrenciler ile devlet üniversitesi öğrencilerinin ilişkide algıladıkları istismar düzeyi ve ilișkide algıladıkları doyumun düzeyi sınıf, ilişki süresi, gelir durumu, ailelerin eğitim düzeyi ve evlilik durumu gibi değişkenlere açısından farklı olup olmadığı ele alınmıştır. Bu amaca uygun olarak çalışmalar iki ayrı üniversitede eş zamanlı olarak gerçekleştirilmiştir. Araştırma sonuçları vakıf üniversitesi öğrencilerinin romantik ilişkilerinde daha fazla doyum yaşadıklarını ortaya koymuştur. Dahası, üst sınıf öğrencileri ve daha uzun süreli ilişki sahibi olanların ilişki doyumu daha yüksek bulunmuştur. Son olarak regresyon analizi sonuçları romantik ilişki doyumunun sırası ile kaçınan bağlanma, romantik ilişkilerde algılanan istismar, kaygılı bağlanma ve ilişkide gelecek yönelimi ile ilişkili olduğu bulunmuştur.

Anahtar Kelimeler: bağlanma boyutları, romantik ilişkilerde doyum, istismar, romant ik ilişkilerde istismar, gelecek yönelimi 
Romantic Relationship Satisfaction Levels of Female University Students in Turkey: Examining through Attachment Dimensions, Perceived Abuse in Relationship and Future Time Orientation of Relationship

Aylin DEMIRLi YILDIZ - Gökçe ÇOKAMAY - Müge ARTAR

\section{INTRODUCTION}

In the eighteenth century, Rousseau called the period between 15-20 years of age puberty and defined adolescence as 'rebirth' in his work "Emile" by his words: "We are born, so to speak, twice over; born into existence, and born into life." However, adolescence being an intermediate phase in which one is neither a child nor an adult, has no social responsibilities but can explore, examine and try out these roles, is a 3staged transitional period throughout which physiological, psychological and social developments occur significantly and rapidly. According to Bloss (1962) these stages are 1) Early Adolescence 2) Middle Adolescence and 3) Late Adolescence.

The intense psychosocial development that is the key feature of adolescence requires the adolescent to develop a realist and positive self-view and identity. When it comes to fields of psychosocial development, as part of identity development, the adolescent would try to perform one's duty to become independent and especially to set oneself free from parents. Other than becoming independent, solving the issues about identity, gaining a realistic and positive self-view and improving vocational qualifications, which are demands of adult life, are among other developmental duties of adolescence. Another important developmental duty of this period is being described as developing relationship skills to get close to the opposite sex, coping with sexual desires and impulses in a healthy way (Erikson, 1968; Feldman and Gowen, 1998). Late adolescence, in today's world is ensuing by emerging adulthood period which is also antecedent of adulthood.

Emerging adulthood lasts until the end of age 20, involving the university years have many developmental tasks. In the period of emerging adulthood, the locus on identity issues in emerging adulthood can be seen in the three main areas of identity exploration: love, work, and worldviews which is the late period of adolescence and early period of adulthood (Arnett, 2000). Hence, the development role particularly coming forward includes developing interpersonal relationship skills such as learning to cope with developing sexuality and reaching the level of mature sexuality as well as the capacity of intimacy in romantic relationships and preparing to be close partners with others (Arnett, 2000).

Romantic relationships, which are crucially important during the emerging adulthood development period, were analyzed in terms of precursors, process and impact throughout the literature. Developing healthy romantic relationships is correlated with the satisfaction level of that relationship. The happiness of relationship and ensuring the stability of the relationship is only possible with relationships that are satisfactory (Metts and Cupach, 1990; Sullivan and Schwebel, 1995; Stackert and Bursik, 2003). Therefore, examining the factors affecting the relationship satisfaction level would be of great importance. According to prior studies relationship satisfaction is correlated with variables such as empathic behavior (Davis and Oathout, 1987), problem solving skills (Metts and Cupach, 1990), conflict behavior (RussellChapin, Chapin and Sattler, 2001), depression (Cramer, 2004), relationship stress (Barnes, Brown, Krusemark, Campbell and Rogge, 2007), communication styles (Olderbak and Figueredo, 2009), perfectionism (Stoeber, 2012) and attachment styles (Towler and Stuhlmacher, 2013). Furthermore, studies focus on the future impact of romantic relationships in emerging adulthood suggests that the romantic relationships during this period have a great deal of effects on developing necessary behaviors for better adjustment to adulthood.

Romantic relationships, which are crucially important in emerging adulthoods' personal and social development, seem to affect one for a lifetime. In this period, emerging adulthoods practice the romantic relationships they will have in their adulthood. The experiences gained at that period of time affect the quality and adjustment level of romantic 
relationships during adulthood (Furman, 2002; Sabetelli, 1988). Young people in emerging adulthood seem to experience a wide range of romantic relationships with the influence of their previous lives and relationship experiences. The effects of those relationships are on different aspects of one's development. Some relationships impact the development positively, prepare one for the next developmental period and ensure one to gain necessary skills for developing supportive relationships in the future. On the other hand, many relationships may involve inhibitory and intense abusive patterns. Additionally, youngsters who fail to develop satisfied relationships tend to feel deeply isolated. Studying the range and premises of romantic relationship, which is influential both on future orientation and in current life, in relation to women who are in emerging adulthood would fill the void in literature.

The current study aimed to look into the romantic relationship satisfaction, which is one of the most important elements during identity formation, of female students in terms of attachment levels, perceived abuse in romantic relationship, and future time orientation in romantic relationship. Socio-demographic attributes of the family were also included in the study since it was observed to be an important variable through the literature. In a study conducted by Foshee et al. (2004), the role of socio-demographic features and social status was examined within abusive romantic relationships. Results of the research showed that; conditions such as being raised in a young family, friends or neighbors' (Ackard, NeumarkSztainer and Hannan, 2003; Foshee et al., 2009) and low socio-economic status, disadvantaged educational background of the family can be considered to be risk factors for romantic relationship abuse (Foshee et al., 2009). According to Hazan and Shaver (1987), one develops an attachment to the person they have a romantic relationship similar to the one they had with their caregiver through their childhood. Romantic relationships, then, involve the sum of previous childhood identifications in which the attachment dimensions and socio economic status of family play a crucial role in formation and cultural conceptualization of being about relations (Steinberg, 1985). The research conducted by Kalkan (2008) discussed the influence of familial factors in future time orientation in romantic relationships. That research suggested that the parents' approach and self-perception of the individual within the family is effective on temporary or long-term romantic relationship orientation.

Bowlby (1969, 1972, and 1980) also suggests that experience of early relationship or mental representations of children are being constructed by their caregivers during childhood (Shorey, Cornelius and Bell, 2008). That is, those early relationship experiences will be consistent in time and will be a template for future relationships. According to attachment theory, individuals tend to choose their romantic relationship partner and maintain their relationships with reference to their early relationship experiences (Waters, Posada, Crowell and Keng-ling, 1993). An ideal experience of early relationship encourage infants to improve their relationships more than the one with their primary caregiver. Through later identifications, the child then tends to admire ones with characteristics or features that are familiar to them. Studies on attachment show that secure attachment is correlated with positively perceived romantic relationships. Individuals who had a secure attachment tend to be more optimistic about their romantic relations (e.g. Carnelley and Janoff-Bulman, 1992), build more consistent relationships (e.g. Kirkpatrick and Davis, 1994), experience higher relationship satisfaction (e.g. Collins and Read, 1990; Simpson, 1990), show more affection and support to those they have a relationship with and communicate healthier (e.g. Collins and Feeney, 2000) than the individuals who had an insecure attachment. Furthermore, as Bowlby (1980) indicates, quality of the relationship with the parent also defines the quality of relationships the infant will develop with others and influences identity development. Therefore, establishing and maintaining close and romantic relationships during adolescence 
Romantic Relationship Satisfaction Levels of Female University Students in Turkey: Examining through Attachment Dimensions, Perceived Abuse in Relationship and Future Time Orientation of Relationship

and emerging adulthood can take place under the shadow of one's childhood, early adolescence experiences and relationships. As Hazan and Shaver (1987) also discussed, individuals who have an avoidant attachment style, which was developed by addressing the fear, failure, dependency requirements experienced during childhood with neglect, criticism or mockery because of the absence or inconvenience of the parent(s), tend to be partners who develop less trusting towards their mates, have negative expectations about the relationship and avoid intimacy. This untrustworthy and distant position may decrease the relationship satisfaction and may also bring about abusive behavior.

Saltzman, Fanslow, McMahon and Shelley (2002) describe abuse in romantic relationships as: "Physical, sexual and emotional harm towards one another within an emotional relationship." In addition, Merrell (2001) explains abuse in a romantic relationship as: "Behaviors and attitudes establishing power and control towards one another or one over another by means of psychological, physical and sexual force within an emotional relationship."

In terms of implementation of abuse during dating period, verbal abuse rates seem to vary between $11 \%$ and $15 \%$ whereas physical abuse rates seem to vary between $9 \%$ and $43 \%$ (Price, and Byers, 1999). The National Violence against Women Study (NVAWS) estimates that lifetime prevalence rates of intimate partner violence are $22.1 \%$ for women and $8 \%$ for men (Tjaden and Thoennes, 2000). In addition, the National Center for Injury Prevention and Control (2003) estimates that 4.5 million intimate partner assaults occur annually.

As it is in domestic violence, abuse in romantic relationships is a type of violence which can be difficult to intervene in for the third parties as individuals try to solve these on their own and keep living with it privately, mostly choosing to hide from others (Aslan, Vefikuluçay, Zeyneloğlu, Erdost and Temel, 2008). Thus, romantic relationships which can be beneficial for the development of youngsters in emerging adulthood, can also turn into a mechanism which can affect the development of late adolescents negatively when it involves violence and abuse. Nevertheless, individuals in an abusive relationship show tendency to continue this relationship. Moreover, interestingly there are studies showing that the length of the relationship increases with the level of abuse (as cited in Choice and Lamke, 1999). Even though this situation may look like a paradox, social judgments according to gender roles that make being in a relationship a priority for women and thus ignorance of this violence can lead individuals to focus on the continuity of their relationship. In other words women sometimes do not realize they are being abused. When the literature is generally reviewed, it can be seen that some of the most important reasons for dating violence are societies' perception of men being superior to women and tolerating erroneous behaviors of men more than those of women (Aslan et al., 2008). The emphasis put on continuity and future of the relationship may make it understandable for women to disregard the abuse in the relationship in some cases (Macke, 2010). In other words, when the woman's primary objective perceive as to be involved in a close relationship and maintain it then she needs to be more adjustable to her partner to be able to ignore conflicts and interpret the violent experiences as acceptable behavior. Research also shows that in relationships with lower satisfaction level, the ones who are less willing to end the relationship are the ones that are more future-oriented individuals. Moreover, some research paradoxically show that as the relationship satisfaction decreases, future orientation increases (Öner, 2001). Other research (Öner, 2002) points out those low self-monitoring individuals have high future time orientation in romantic relationships, which means they tend to make prudential plans about the long-term relationship and have higher measures of attachment. 
Reviewing Turkey specifically it is witnessed that research suggest women have to deal with abuse and violence in their relationships. According to data of Turkish Statistical Institute on Violence Against Women (2008), the percentage of women who experienced physical violence from their spouse or partner in any period of life is $39.3 \%$, percentage of those who were sexually violated is $15.3 \%$, women who experienced physical or sexual violence is $41.9 \%$, those who experienced emotional violence/abuse is $43.9 \%$ and in the context of being exposed to controlling behavior, percentage of needing to know where the other person at all times is $68.8 \%$, forbidding to see friends is $12.4 \%$. As it can be seen by these values, violence in close relationships is widespread in this country. Within the studies conducted with university students, Dogan (2012) in his research examined the problem areas of students who got help from the counseling center between years 1997-2008, and determined that problems in romantic relationships are one of the most important problem areas for university students. Another research study emphasized that university students may have the tendency to recognize the primary objective of women as establishing a close relationship and in order to sustain the relationship she may not care about the conflicts and may regard violent experiences as acceptable (Kepir-Savoly, Ulaş, and Demirtaş-Zorbaz, 2014). Kaygusuz (2013) pointed that irrational romantic relationship beliefs are positively correlated with physical abuse in the relationship, emotional abuse and problem solving behaviors'.

As in Turkey, the situation seems to be concerning women who are university students throughout the world as well as women in lower SES. Limited numbers of studies were conducted on university students and those studies conducted in different cultures demonstrate that women university students have to cope with abuse and violence in their relationship. For example, Aluede, Imhonde and Eguavoen (2006) determined that $22 \%$ of Nigerian university students who applied to the psychological counseling center in university for aid had been through relationship problems and $7.4 \%$ of them were sexually harassed. Another study conducted at an urban Australian University showed that $45.7 \%$ of university students applied to the psychological counseling center because of emotional problems and $4.3 \%$ due to sexual harassment (Schweitzer, 1996).

To that end, one of the main objectives of this study is to understand the role of perceived abuse, attachment dimension and future orientation in relationship satisfaction of female university students in two different universities where one is a state university and the other one private. The reason selecting one private and one state university is to understand whether there is a difference among the perception of students due to their families' socioeconomic status with the assumption that cultural background has an important role in perceiving abuse as well as determining the value of romantic relationship. To sum up, the main research question of the study is:

1. To what extent can relationship satisfaction be predicted from attachment dimensions, perceived abuse in relationship and future time orientation of relationship?

The other research questions are if there any difference among;

a. Relationship satisfaction in state and private universities with respect to grades, relationship durations, family income, mothers' and fathers' education level and marital status of parents?

b. Perceived abuse in relationship in state and private universities in relation to grades, relationship durations, family income, mothers' and fathers' education level and marital status of parents?

\section{METHOD}


Romantic Relationship Satisfaction Levels of Female University Students in Turkey: Examining through Attachment Dimensions, Perceived Abuse in Relationship and Future Time Orientation of Relationship

Aylin DEMIRLi YILDIZ - Gökçe ÇOKAMAY - Müge ARTAR

This chapter involves the description of the methodological procedures of the study. First, the demographic information about participants, and the procedures related to sampling are presented. Then, data collection instruments of the study are given together with their psychometric properties, reliability, and validity processes. Finally, procedures for data collection, and methods for data analysis are presented.

\subsection{Participants}

The data for the present study was collected from undergraduate students enrolled in two different education faculties, one is a state university, which is Ankara University and other one is a private university, which is Başkent University during the spring semester of 2013-2014 academic year by convenience sampling method. It is aimed to understand the role of being a student of state or private universities, as well as grades, relationship durations, family income, mothers' and fathers' education level and marital status of parents' among perceived abuse in relationship and satisfaction in relationship. To that end, we carried out the research in two different universities whose students have different socio-economic background with the assumption that it has an important role in perceiving abuse as well as in determining the value of romantic relationship. 410 university students volunteered in the study with the mean age of 23 . Among them, 257 (62.7\%) of the participants are from Ankara University, 153 (37.3\%) participants are from Başkent University. 83 (20.2 \%) participants are freshmen, 59 (14.4\%) participants are sophomore, 95 (23.2 \%) participants are junior, 115 (28 $\%)$ participants are senior students.

Relationship status and durations are also examined in study. It is found that 29 (7.1\%) participants had relationships for less than 1 month, 35 (8.5\%) participants had relationships for between 1 to 3 months, 41 (10.0\%) participants had relationships for between 3 to 6 months, $58(14.1 \%)$ participants had relationships for between 6 month to one year. In addition to these, 74 (18.0\%) participants had relationships lasting between 1 to 2 years, 93 (22.7\%) participants had relationships for between 2 to 4 year, $42(10.2 \%)$ participants had relationships lasting between 4 to 6 years, and 31 (7.6\%) participants had relationships lasting 6 years and more. Moreover, $348(84.9 \%)$ participants noted that their parents were married and living together, while $25(6.1 \%)$ reported that their father or mother was dead, $4(1.0 \%)$ participants reported that both of their parents were dead, $22(5.4 \%)$ stated their parents were divorced, 7 (1.7\%) participants' parents were married but they did not live together, 4 (1.0\%) participants' parents did not live together because of their jobs.

\subsection{Data Collection Instruments}

Data collection instruments which are demographic Information Form, Relationship Assessment Scale, Future Time Orientation in Romantic Relationships Scale, Experiences in Close Relationships-Revised Inventory and Romantic Relationship Assessment Inventory clarified in this part of study.

\subsubsection{Demographic Information Form}

Demographic Information Form was prepared by the researchers in order to gather information about the participants including their age, university, grade level, family economic status, and togetherness status of parents.

\subsubsection{Relationship Assessment Scale (RAS)}

This scale was developed by Hendrick in 1988 to measure the satisfaction individuals get from their romantic relationships. The total score obtained from the scale shows how much satisfaction one gets from their relationship. The highest score indicates highest 
satisfaction. Within the scale, a footnote was given to inform those who were not in a romantic relationship at the time of the execution of the scale to answer the questions in the scale assuming their last relationship. The factor analysis of the scale with a single factor (Hendrick, 1988) showed $46 \%$ of the total variance can be explained. Item-total correlation differed between .57 and .76 .

Turkish adaptation of study was carried out by Çelik (2014) with data collected from 336 married couples. For structural validity, confirmatory factor analysis was done. Confirmatory factor analysis provided a good fit to the data $\left(x^{2}=52.87, \mathrm{df}=13, p=0.00\right.$, RMSEA $=.069, \mathrm{GFI}=.95, \mathrm{CFI}=.97, \mathrm{IFI}=.97, \mathrm{NFI}=.95$, and SRMR $=.04)$. The internal consistency coefficient was found .87 . In the result of the item analysis, corrected item-total correlations ranged from a low of .52 to a high of .74 , and were statistically significant at the $p$ $<0.001$. The reliability of the scale was examined with internal consistency and split-half test methods. Scale's internal consistence reliability coefficient was $\alpha=.87$. (Çelik, 2014).

\subsubsection{Future Time Orientation in Romantic Relationships Scale (FTORR)}

Future Time Orientation in Romantic Relationships Scale was developed by Oner (2000). Seven items in the scale were then extended with four other items focusing on current romantic relationship. A few examples from the scale are "I prefer to enjoy the present time without considering the future of my relationships with the opposite sex", or "I usually think about and make plans about the future of my romantic relationships". The answers given to the quadruple likert-type scale differed from "this is not at all accurate to me" to "this is very accurate to me". The highest score of the scale indicated one has higher future time orientation in a romantic relationship. The scores of this scale can change between 11 and 44 . The Cronbach alpha internal consistency coefficient was .81 of the scale.

\subsubsection{Experiences in Close Relationships-Revised Inventory (ECR-R)}

The Experiences in Close Relationships Questionnaire was developed by Fraley, Waller, and Brennan (2000). ECR-R is a 36- item 7-point Likert type self-report measure of adult attachment. More specifically, it measured adult attachment within the context of romantic relationships. 18-item sub scales measured anxiety and avoidance dimensions of attachment. The anxiety sub scales measured one's self-reported degree of anxiety in romantic adult relationships, whereas avoidance assessed the extent of avoidance of intimacy in such relationships. Fraley, Waller and Brennan (2000) examined reliability coefficients of the ECR-R in comparison with the Adult Attachment Scale-AAS, (Collins and Read, 1990); the Relationship Style Questionnaire-RSQ, (Griffin and Bartholomew, 1994); and the Experiences in Close Relationships-ECR, (Brennan, Clark, and Shaver, 1998). The ECR-R had higher test re-test reliability coefficients ranging from .93 to .95 then the other measures.

Selçuk, Günaydın, Sümer, and Uysal (2005) adopted the ECR- R into Turkish. In this study, the items were loaded in two factors as had been done in the original study. The internal consistencies of attachment avoidance and anxiety sub scales were found to be satisfactory (.90 and .86, respectively). Selçuk et al. (2005) also found that the ECR- R Turkish version had high test- retest reliability. Coefficients were .81 for avoidance sub scale and .82 for anxiety sub scale.

\subsubsection{Romantic Relationship Assessment Inventory (RRAI)}

Items of the single-dimensional scale had a five-point Likert type answering system. RRAl contained 70 items and did not involve any items scored in the reverse order. Items can be answered as "never", "rarely", "sometimes", "frequently" and "very frequently". In the scoring, "never" was given 1, "rarely" was given 2, "sometimes" was given 3, "frequently' was 
Romantic Relationship Satisfaction Levels of Female University Students in Turkey: Examining through Attachment Dimensions, Perceived Abuse in Relationship and Future Time Orientation of Relationship

Aylin DEMIRLi YILDIZ - Gökçe ÇOKAMAY - Müge ARTAR

given 4 and "very frequently" was given 5 points. The lowest score of the scale was 70 and highest score was 350 and increased score meant increased levels of abuse experienced in the romantic relationship. It was seen that there were 13 dimensions with an eigenvalue higher than 1, and that these dimensions explained $64.89 \%$ of the total variance. It was observed that the first dimension explained the total variance in $33.50 \%$ with an eigenvalue of 23.45 . It was determined that the Cronbach Alpha reliability coefficient of the inventory is 0.97 . For test re-test reliability of the RRAI, rank-order correlation was calculated as $0.89(p<0,001)$. Rankorder correlation between the RRAI and Relationship Satisfaction Scale points was determined as $-0.76(p<0.001)$.

\subsection{Data Collection Procedure}

Initially, the necessary permission was granted from both Ankara University and Başkent University Ethics Committees. The researchers collected data in a 6-week period during the 2013-2014 academic year spring semester. Six hundred booklets including demographics form and other measures of the study were given to each participant during regular classroom hours. Volunteered students completed the questionnaire at the end of the regular class hours. The students were told that they were free not to fill out the questionnaires and hence not to participate in the study. To ensure confidentiality and anonymity, the participants were not asked for any identifying information. The questionnaires were administered in the following order: Demographics Information Form, RAS, Experiences in Close Relationships-Revised Inventory (ECR-R), Future Time Orientation Scale (FTORR), and Romantic Relationship Assessment Inventory (RRAI). It took the participants about 30 minutes to complete the questionnaire. After the completion of the questionnaires, the participants were thanked for their participation.

\subsection{Data Analysis}

In accordance with the objectives of the study the theoretical relationships among dependent, and independent variables were investigated through variance analyses and regression analysis. Before conducting the variance analyses, linearity, independence of observations, normality, homoscedasticity and correlational values were tested for variance analyses and regression analysis.

Firstly, variance analyses were conducted to understand the relation of perceived abuse in romantic relationship in terms of some demographic features, which were university, grade, and duration of romantic relationship, family income and marital status of parents. Secondly, Hierarchical Regression a statistical method of testing hypotheses about, a dependent variable and several independent variables and exploring the relationship among them, was conducted since it is typically used to evaluate the relationship between the set of independent variables and the dependent variable, taking into account the impact of a different set of independent variables on the dependent variable. The hierarchical model calls for a determination of $R^{2}$ as well as that of the partial coefficients of each variable at the point at which it is added to the equation. In hierarchical regression, the independent variables are entered into the analysis in a sequence of blocks, or groups that may contain one or more variables (Tabachnick and Fidell, 2007).

\section{RESULTS}

In the results section of the study, firstly descriptive statistics and preliminary analysis then relation of individuals' demographic characteristics with perception of relationship abuse and relationship satisfaction and hierarchical regression model analysis will be given in sequence. 


\subsection{Design and Preliminary Analysis}

Firstly, missing value analysis was conducted to find the patterns of missing data. Findings of univariate statistics indicate that there was no missing value of all major variables more than 5. Moreover, separate variance t-tests were performed to highlight the patterns of missing data. Results showed no systematic relationship between missingness of variables. Analyses provided evidence that data are missing randomly.

In order to test normality, descriptive statistics, including mean, standard deviation, skewness, kurtosis and histograms were conducted. Results of these statistics demonstrated that normality was not violated. Before conducting the analysis, major assumptions of the multiple regression analysis were tested. Table 1 shows descriptive statistics of variables and coefficient correlations. In addition, multicollinearity was tested and no inter-correlation was found above .70. Additionally, tolerance and VIF values were used for indicators of multicollinearity, and Durbin-Watson was used to test the autocorrelation of variables. As a result, considering the acceptable values (Tabachnick and Fidell, 2007) multicollinearity and autocorrelations of independent variables were not detected in the present data.

\section{Table 1}

Means and Standard Deviations and Correlations of Relationship Satisfaction, Attachment Dimensions, Perceived Abuse in Relationship, Future Time Orientation of Relationship

\begin{tabular}{lcrlllll}
\hline & & \multicolumn{7}{c}{ Correlations } \\
\cline { 5 - 8 } & $\mathrm{M}$ & \multicolumn{1}{c}{$\mathrm{SD}$} & 1 & 2 & 3 & 4 & 5 \\
\hline 1.Relationship Satisfaction & 32.50 & 8.38 & .00 & & & & \\
2. Anxiety & 3.55 & .99 & $.42^{*}$ & .00 & & & \\
3. Avoidance & 3.18 & .96 & $.43^{*}$ & .47 & .00 & & \\
4.Perceived Abuse In Relationship & 94.40 & 29.61 & $.36^{*}$ & .27 & .23 & .00 & \\
5.Future Time Orientation & 33.92 & 5.23 & $.16^{*}$ & .01 & .02 & .04 & .00 \\
\hline
\end{tabular}

As seen in Table 1, relationship satisfaction was correlated negatively with anxiety ( $r=$ $.42, p<.001)$, with avoidance dimensions $(r=-.43, p<.001)$ of the attachment scale. Moreover, there was a negative correlation between relationship satisfaction and perceived abuse in relationship $(r=-.36, p<.001)$. On the other hand, relationship satisfaction was positively correlated with future time orientation of relationship $(r=.16, p<.001)$. Lastly, avoidance and anxiety sub scales were correlated significantly positively with each other $(r=.47, p<.001)$.

3.1.1 Part 1: Relation of Individuals' Demographic Characteristics with Perception of Relationship Abuse and Relationship Satisfaction

As part of the study, variance analyses were conducted to understand the relation of perceived abuse in romantic relationship in terms of some demographic features, which were university, grade, and duration of romantic relationship, family income and marital status of parents. Firstly, the results showed that there was a significant difference between Ankara University being the state university and Baskent university as the private one in terms of perceived abuse in romantic relationship, $F(3,406)=4,672, p<.01$. It was also found that, female students in Ankara University had more satisfaction in their romantic relationships than students in Başkent University. Secondly, it was found that there was a significant difference 
Romantic Relationship Satisfaction Levels of Female University Students in Turkey: Examining through Attachment Dimensions, Perceived Abuse in Relationship and Future Time Orientation of Relationship

Aylin DEMIRLi YILDIZ - Gökçe ÇOKAMAY - Müge ARTAR

between grades $\left(2^{\text {nd }}\right.$ to $4^{\text {th }}$ grade) in terms of RAS $F(5,404)=2.86, p<.01$. Therefore, female students in $4^{\text {th }}$ grade had more satisfaction in their relationships than students in $2^{\text {nd }}$ grade. Finally, there was a significant difference between relationship durations in terms of perceived abuse in romantic relationship, $F(7,395)=6.72, p<.01$. According to findings, the students who had a relationship less than 1 month had less relationship satisfaction than the students who had a relationship between 6 month-1 year, 1-2 years, 2-4 years, 4-6 years, and more than 6 years. Also, the students who had a relationship lasting 3-6 months had less relationship satisfaction than the ones with relationships lasting 1-2 years, 2-4 years, 4-6 years and more than 6 years.

Moreover, One-way ANOVA was conducted to see the differences of family income and marital status of parents on total score of Relationship Assessment Scale (RAS). According to findings, there were no significant differences between family income status and marital statuses in terms of perceived abuse in romantic relationship. To see the differences of mother and fathers' education level, on total score of Relationship Assessment Scale (RAS) One-way ANOVA was conducted. As variances did not show homogeneity, Kruskal-Wallis, which is a non-parametric test, was resorted to for analysis. According to findings, there were no significant differences between those variables in terms of RAS. Moreover, according to analysis, there was a negative correlation between age and RAS, $r=-.12, p<.01$. In addition, according to findings, while age increased, relationship satisfaction decreased.

\subsubsection{Part 2: Model Summary of Hierarchical Multiple Regression Analysis}

Hierarchical analysis of the variables typically adds to the researcher's understanding of the phenomena being studied, as it requires thoughtful input by the researcher in determining the order of entry of independent variables, and yields successive tests of the validity of the hypotheses, which determine that order (Tabachnick and Fidell, 2007). In the study, avoidance and anxiety dimensions were entered in the first block, perceived abuse in relationship was entered in the second block and future orientation in relationship was entered as the third block.

A hierarchical regression analysis was conducted to examine the extent to which independent variables, namely attachment dimensions, measured as anxiety and avoidance, perceived abuse in romantic relationship and future time orientation of romantic relationship predicted relationship satisfaction. Standardised regression coefficients $(\beta), t$ values, partial correlation coefficients, zero-order correlation coefficients, and part correlation coefficients of the models are presented in Table 2 .

\section{Table 2}

Model Summary of Hierarchical Multiple Regression Analysis and the Bivariate and Partial Correlations and the Significance Levels of $B$

\begin{tabular}{|c|c|c|c|c|c|c|c|}
\hline \multirow[b]{2}{*}{ Model } & \multirow[b]{2}{*}{$R^{2}$} & \multirow[b]{2}{*}{$\Delta \mathrm{R}^{2}$} & \multirow[b]{2}{*}{$\beta$} & \multicolumn{3}{|c|}{ Correlations } & \multirow{2}{*}{$\begin{array}{l}\text { Durbin- } \\
\text { Watson }\end{array}$} \\
\hline & & & & $\begin{array}{l}\text { Zero- } \\
\text { order }\end{array}$ & Partial & Part & \\
\hline
\end{tabular}

(Constant) $\quad .19^{*} \quad .19^{*}$




\begin{tabular}{|c|c|c|c|c|c|c|c|}
\hline Avoidance & & & $.43 *$ & -.43 & -.43 & -.43 & \\
\hline (Constant) & $.25^{*}$ & $.24^{*}$ & & & & & \\
\hline Avoidance & & & $.30 *$ & -.43 & -.30 & -.27 & \\
\hline Anxiety & & & $.27 *$ & -.42 & -.27 & -.24 & \\
\hline (Constant) & $.30 *$ & $.30 *$ & & & & & \\
\hline Avoidance & & & $.27 *$ & -.43 & -.28 & -.24 & \\
\hline Anxiety & & & $.22 *$ & -.42 & -.23 & -.19 & \\
\hline Perceived Abuse & & & $.24 *$ & -.36 & -.26 & -.23 & \\
\hline (Constant) & $.32 *$ & $.32 *$ & & & & & \\
\hline Avoidance & & & $.27^{*}$ & -.43 & -.28 & -.24 & \\
\hline Anxiety & & & $.23 *$ & -.42 & -.23 & -.20 & \\
\hline $\begin{array}{l}\text { Perceived } \\
\text { Abuse }\end{array}$ & & & $.23 *$ & -.36 & -.26 & -.22 & 1.80 \\
\hline $\begin{array}{l}\text { Future } \\
\text { Orientation }\end{array}$ & & & $15^{*}$ & .16 & .18 & .15 & \\
\hline
\end{tabular}

1. Predictors: (Constant), Avoidance

2. Predictors: (Constant), Avoidance, Anxiety

3 Predictors: (Constant), Avoidance, Anxiety, Perceived Abuse

4. Predictors: (Constant), Avoidance, Anxiety, Perceived Abuse, Future Orientation

Dependent Variable: Romantic Relationship Satisfaction

In the overall model, attachment dimensions which were avoidance and anxiety, perceived abuse in relationship, and future time orientation of relationship significantly predicted relationship satisfaction with beta values of $b=-.27, p<.01 ; b=-.23, p<.01 ; b=-.23$, $p<.01$; and $B=.15, p<.01$, respectively. The avoidance attachment dimension significantly predicted relationship satisfaction, $R^{2}=.19 \Delta \mathrm{R}^{2}=.19, F(1,408)=95.37, p=.00$. The regression equation with both the avoidance and anxiety dimensions was also significant, $R^{2}=.25, \Delta R^{2}=$ $.24, F(1,407)=31.66, p=.01$. In addition, the regression equation of perceived abuse in relationship and attachment dimensions was significant, $R^{2}=.30, \Delta \mathrm{R}^{2}=.30, F(1,406)=30.63, p$ $=.01$.

Finally, the regression equation of avoidance and anxiety dimensions of attachment was significant, $R^{2}=.32, \Delta \mathrm{R}^{2}=.32, F(1,405)=13.53, p=.00$, for family environment and gender, indicating that $32 \%$ of the variance in relationship satisfaction is explained by all factors operating jointly. To understand the unique contribution of each variable to the prediction of loneliness, partial and zero-order bivariate correlations were reported for each of the individual variables in attachment dimensions, perceived abuse in relationship and future time orientation of relationship. Of these variables, avoidance and anxiety dimensions were the strongest predictors of relationship satisfaction. Eliminating the effects of other predictors, all variables, namely avoidance dimension, anxiety dimension, perceived abuse in relationship and future time orientation of relationship, were significantly correlated with relationship satisfaction; and among them, the avoidance dimension was the most strongly correlated 
Romantic Relationship Satisfaction Levels of Female University Students in Turkey: Examining through Attachment Dimensions, Perceived Abuse in Relationship and Future Time Orientation of Relationship

Aylin DEMIRLi YILDIZ - Gökçe ÇOKAMAY - Müge ARTAR

variable. Strength of the partial correlation between avoidance and relationship satisfaction was .43 $(p=.00)$ and between anxiety, avoidance and relationship satisfaction was .30 $(p=$ $.00)$.

\section{Discussion}

The results of the analyses suggested that socio demographic variables, grade level, and duration of the relationship were correlated with relationship satisfaction. What is more, age was found negatively correlated with relationship satisfaction whereas there was no significant correlation between income, education status and marital status of the family and relationship satisfaction. Research findings seemed to be consistent with the analyses of other researchers. A recent study by Saraç, Hamamcı and Güçray (2015) suggested that gender, age, duration of relationship and class level does not significantly predict the relationship satisfaction. Parallel to the findings of the study, studies of Büyükşahin (2006) and Buğa (2009) found that relationship status significantly predicts satisfaction.

The fact that there was no significant correlation found between socio-demographic characteristics of the family and romantic relationship satisfaction was one of the most thought provoking results of the study considering the correlation displayed by attachment dimensions. According to the results of the study, a moderately significant correlation was found between anxiety and avoidance dimension of the attachment and relationship satisfaction. After the attachment dimensions, perceived abuse in relationship was also found to be in correlation with relationship satisfaction. Lastly, it was found that there was a low significant correlation between future time orientation in romantic relationships and relationship satisfaction.

One of the highlights of the study was that attachment dimensions showed more correlation than perceived abuse in relationship. This situation can be explained by the assumption that university students with avoidant attachment styles may have a hard time trusting their friends thus perceive abuse as a natural part of the relationship. Simpson (1990), and Kesner and McKenry (1998) found a significant correlation between avoidant attachment style and spousal abuse. Along with the avoidant attachment style, anxious attachment dimension was also correlated with relationship satisfaction. It can be said that for individuals who have anxious attachment, to feel worthless and to have low self-esteem play an important role in accepting abuse in romantic relationships (Bartholomew and Horowitz, 1991). In other words, university students with anxious attachment style have positive expectations from their partner about their romantic relationship, and this may lead them to see the abusive behaviors of their partner as a natural part of this relationship (Kılınçer, 2012).

Another explanation why the correlation of abuse and relationship satisfaction was found to be lower than expected is the effects of common cultural features in Turkey. It can be seen that there is a stereotyped thought that men have the strength and power over the relationship whereas women seem to have an accepting attitude towards this stereotyped thought full of power and violent behavior when the common cultural features of Turkey examined (Vefikuluçay, Zeyneloğlu, Eroğlu and Taşkın, 2007). Having these kinds of stereotyped judgments about romantic relationships can lead to problems in the relationship and couples may engage in physical and psychological violent acts towards each other. In fact, gender roles have a very important role on accepting and engaging in violence in romantic relationships (Aslan et al., 2008).

The least predictive variable of the study was future time orientation in romantic relationship even it was still significant. It is relevant with studies like Oner's (2000) indicating 
that general planning for the future was a helpful characteristic in terms of relationship satisfaction, while a high demand for commitment in a relationship negatively affect romantic relationship satisfaction. Gürcan (2015) found that no significant correlation between future time orientation and romantic relationship satisfaction among university students.

In a study conducted by Kalkan (2008), the effect of family related factors on future time orientation was discussed. Research pointed out that parents' manner of approaching the child and individual's self-perception within the family influence temporary or long-term romantic relationship orientation. Romantic relationships that are experienced and that bear the traces of the past during university years in which cognitive, social and emotional changes occur also have a very important role on shaping an individual's future. Considering that individuals' behaviors and interaction patterns displayed on their romantic relationships are the ones that come along with their families, it can be seen that they try to solve their current relationship problems with changing the traces of the past (Goldenberg and Goldenberg, 1996). To this end, knowing the family history increases the predictability of future generations (Bowen, 1981).

As a result, being involved in a romantic relationship is a developmental duty of emerging adults to explore their identity. According to research conducted within this study, female university students' attachment dimensions and perceived abuse in relationship seem to influence their relationship satisfaction as well as future time orientation. As Furjman and Schaffer (2003) stated that romantic relationships experienced during emerging adulthood period, provide important opportunities to develop necessary behaviors for better adjustment to adulthood. Therefore, psychological counseling services can be provided in psychological counseling departments of the universities in order to help students cope with their problems in romantic relationships. This psychological support can be more effective by the attendance of both parties of the relationship. Moreover, various educational programs can be prepared in universities for individuals to be more sensitive about their partners' individual rights and freedom and for them to form realistic and healthy relationships with their partners providing relationship satisfaction. Strategies can be developed according to the findings of these studies.

Lastly, it is worth mentioning the limitations of study. One of the limitations is that not all of the participants were in a relationship. Researchers asked them to think about the recent relationship because taking out the female university students who did not have any romantic relationship then would be a risk of decreasing the number of participants. Another limitation of study was its cultural bounds. It was conducted in the capital city of Turkey and it is not possible to validate the results of study to the university students in conservative provinces. Moreover, additional research can be conducted in order to analyze the intercultural differences to understand the relevance of results with other cultures. The present study, which was conducted with university students, can also be conducted with adult groups or different occupational groups in order to reveal any differences in adult groups with different occupational features.

\section{REFERENCES}

Ackard, D. M., Neumark-Sztainer, D., \& Hannan, P. (2003). Dating violence among a nationally representative sample of adolescent girls and boys: Associations with behavioural and mental health. Journal of Gender-Specific Medicine, 6, 39-48.

Aluede, O., Imhonde, H., \& Eguavoen, A. (2006). Academic, career and personal needs of Nigerian University students. Journal of Instructional Psychology, 33(1), 50-57. 
Romantic Relationship Satisfaction Levels of Female University Students in Turkey: Examining through Attachment Dimensions, Perceived Abuse in Relationship and Future Time Orientation of Relationship

Aylin DEMIRLi YILDIZ - Gökçe ÇOKAMAY - Müge ARTAR

Arnett, J. J. (2000). Emerging Adulthood: A theory of development from the late teens through the twenties. American Psychologist, 5(55), 469-480.

Aslan, D. Vefikuluçay, D. Zeyneloğlu, S.Erdost, T. \& Temel, F. (2008), Ankara'daki Iki Hemşirelik Yüksekokulunun Birinci ve Dördüncü Sınıflarında Okuyan Öğrencilerinin Flört Şiddetine Maruz Kalma, Flört ilişkilerinde Şiddet Uygulama Durumlarının ve Bu Konudaki Görüşlerinin Saptanması Araştırması, http://www.huksam.hacettepe.edu.tr/Turkce/SayfaDosya/flort_siddeti.pdf Accessed 15 October 2016.

Barnes, S., Brown, K.W., Krusemark, E., Campbell, W.K. \& Rogge, R.D. (2007). The role of mindfulness in romantic relationship satisfaction and responses to relationship stress. Journal of Marital and Family Therapy, 33(4), 482-500.

Bartholomew, K. \& Horowitz, L.M. (1991). Attachment styles among young adults: a test of a four-category model. Journal of Personality and Social Psychology, 61(2), 226-244.

Blos, P. (1962). On adolescence: a psychoanalytic interpretation. Glencoe, IL: Free Press.

Bowen, M. (1981). Family therapy in clinical practice. Northvale, NJ: Jason Aronson.

Bowlby, J. (1969). Attachment and loss, Vol. 1: Attachment. New York, NY: Basic Books.

Brennan, K. A., Clark, C. L., \& Shaver, P. R. (1998). Self-report measurement of adult romantic attachment: An integrative overview. In J. A. Simpson \& W. S. Rholes (Eds.), Attachment theory and close relationships (pp. 46-76). New York: Guilford Press.

Büyükşahin, A. (2006). Yakın iliş̧ilerde bağlanım: yatırım modelinin bağlanma stilleri ve bazı iliş̧isel değişkenler yönünden incelenmesi. Yayınlanmamış Doktora Tezi, Ankara Üniversitesi Sosyal Bilimler Enstitüsü, Ankara.

Buğa, D. (2009). Yakın ilişkilerde istikrar: Bağlanma stilleri ve toplumsal cinsiyet rolleri açısından bir karşılaştırma. Yayınlanmamış Doktora Tezi, Ankara Üniversitesi Sosyal Bilimler Enstitüsü, Ankara.

Carnelley, K. B., \& Janoff-Bulman, R. (1992). Optimism about love relationships: General vs specific lessons from one's personal experiences. Journal of Social and Personal Relationships, 9, 5-20, doi:10.1177/0265407592091001

Choice, P. \& Lamke, L.K. (1999). Stay/leave decision-making processes in abusive dating relationships. Personal Relationships, 6(3), 351-367.

Collins, N. L., \& Read, S. J. (1990). Adult attachment, working models, and relationship quality in dating couples. Journal of Personality and Social Psychology, 58(4), 644-663.

Collins, N.L. \& Feeney, B.C. (2000). A Safe Haven: An Attachment Theory Perspective on Support Seeking and Caregiving in Intimate Relationships. Journal of Personality and Social Psychology, 78(6), 1053-1073.

Connolly, J. A., \& Konarski, R., 1994. "Peer Self-Concept in Adolescence: Analysis of Factor Structure and of Associations with Peer Experience". Journal of Research on Adolescence, 4, 385-403.

Cramer, D (2004) Emotional support, conflict, depression and relationship satisfaction in a romantic partner. Journal of Psychology, 138 (6), 532-542.

Curun, F. (2001). The effects of sexism and sex role orientation on romantic relationship satisfaction. Yayınlanmamış Yüksek Lisans Tezi, ODTÜ, Ankara. 
Çelik, E. (2014). Adaptation of relationship assessment scale to Turkish culture: study of validity and reliability. International Journal of Psychology and Educational Studies, 1(1), 1-7.

Davis, M. H., \& Oathout, H. A. (1987). Maintenance of satisfaction in romantic relationships: Empathy and relational competence. Journal of Personality and Social Psychology, 53, 397-410.

Doğan, T. (2012). A long-term study of the counseling needs of Turkish university students. Journal of Counseling \& Development, 90, 91-96.

Erikson, E. H. (1968). Identity: Youth and crisis. New York: W. W. Norton.

Feldman, S., \& Gowen, C. (1998). Conflict negotiation tactics in romantic relationships in high school students. Journal of Youth and Adolescence, 27(6), 691-705.

Foshee, V. A., Bauman, K. E., Ennett, S. T., Linder, G. F., Benefield, T., \& Suchindran, C. (2004). Assessing the long-term effects of the Safe Dates program and a booster in preventing and reducing adolescent dating violence victimization and perpetration. American Journal of Public Health, 94, 619-624.

Foshee, V. A., Benefield, T., Suchindran, C., Ennett, S. T., Bauman, K. E., Karriker-Jaffe, K. J., et al. (2009). The development of four types of adolescent dating abuse and selected demographic correlates. Journal of Research on Adolescence, 19, 380-400.

Fraley, R. C., Waller, N. G., \& Brennan, K. A. (2000). An item-response theory analysis of selfreport measures of adult attachment. Journal of Personality and Social Psychology, 78, 350-365.

Furjman, W. \& Schaffer, L. (2003). The Role of Romantic Relationships in Adolescent Development. In P. Florsheim (Ed.), Adolescent Romantic Relations and Sexual Behavior: Theory, Research, and Practical Implications. Mahwah, NJ: Erlbaum.

Furman, W. (2002). The emerging field of adolescent romantic relationships. Current Directions in Psychological Science, 11(5), 177- 180.

Goldenberg, I \& Goldenberg, H. (1996). Family therapy: An overview. Pasific Grove, CA: Brooks/Cole.

Gürcan, T. (2015). ilişkisel belirsizlik: İlişki doyumu, romantic ilişkilerde gelecek zaman yönelimi ve çatışma çözme tepkileri arasındaki ilişkiler. Yayımlanmamış Yüksek Lisans Tezi, Sosyal Bilimler Enstitüsü/Ankara Üniversitesi, Ankara.

Hazan, C. \& Shaver, P. (1987). Romantic Love Conceptualized as an Attachment Process. Journal of Personality and Social Psychology, 52(3), 511-524.

Hendrick, S.S (1988). A generic measure of relationship satisfaction. Journal of Marriage \& The Family, 50(1), 93-98, Doi:10.2307/352430.

Kalkan, M. (2008). Do psychological birth order positions predict future time orientation in romantic relationships? Interpersona, 2(1), 89-101.

Kaygusuz, C. (2013). Irrational beliefs and abuse in university students' romantic relations. Eurasian Journal of Educational Research, 51, 141-156.

Kepir-Savoly, D., Ulaş, Ö. \& Demirtaş-Zorbaz, S. (2014). Üniversite Öğrencilerinin Çiftler Arası Şiddeti Kabul Düzeylerini Etkileyen Etmenler. Türk Psikolojik Danışma ve Rehberlik Dergisi. 5(42), 173-183. 
Romantic Relationship Satisfaction Levels of Female University Students in Turkey: Examining through Attachment Dimensions, Perceived Abuse in Relationship and Future Time Orientation of Relationship

Aylin DEMIRLi YILDIZ - Gökçe ÇOKAMAY - Müge ARTAR

Kesner, J.E. \& McKenry, P.C. (1998). The role of childhood attachment factors in predicting male violence toward female intimates. Journal of Family Violence, 13(4), 417-432.

Kılınçer, A.S. (2012). Üniversite Öğrencilerinin Romantik ilişkilerinde Algıladıkları İstismar. Yayınlanmamış Yüksek lisans Tezi, Hacettepe Üniversitesi Sosyal Bilimler Enstitüsü, Ankara.

Kirkpatrick, L.A \& Davis, K.E. (1994). Attachment style, gender, and relationship stability: A longitudinal analysis. Journal of Personality and Social Psychology, 66, 502-512.

Macke, C. A. (2010). Adult romantic attachment as a risk factor for intimate partner violence victimization. University of Kentucky, ProQuest Dissertations Publishing, 3451424.

Merrell, J. (2001). Social support for victims of domestic violence. Journal of Psychosocial Nursing \& Mental Health Services, 30 (11), 30-34.

Metts, S. \& Cupach, W. R. (1990). The influence of relationship beliefs and problem solving responses on satisfaction in romantic relationships. Human Communication Research, $17,170-185$.

National Center for Injury Prevention and Control (2003). Costs of intimate partner violence against women in the United States. Atlanta, GA: Centers for Disease Control and Prevention.

Olderbak, S., \& Figueredo, A. J. (2009). Predicting romantic relationship satisfaction from life history strategy. Personality and Individual Differences, 46, 604-610, doi: 10.1016/j.paid.2008.12.019

Öner, B. (2000a). Relationship satisfaction and dating experience: Factors affecting future time orientation in relationships with the opposite sex. The Journal of Psychology, 134(5), 527-536.

Öner, B. (2000b). Future time orientation and relationships with the opposite sex. The Journal of Psychology, 134(3), 306-314.

Öner, B. (2001). Factors predicting future time orientation for romantic relationships with the opposite sex. The Journal of Psychology, 135, 430-438.

Öner, B. (2002). Self-monitoring and future time orientation in romantic relationships. The Journal of Psychology, 136(4), 420-424

Price, E. L., Byers, E. S., \& the Dating Violence Research Team (1999). The Attitudes Towards Dating Violence Scales: Development and initial validation. Journal of Family Violence, 14, 351-375.

Russell-Chapin, L.A., Chapin, T.J. \& Sattler, L.G. (2001). The Relationship of Conflict Resolution Styles and Certain Marital Satisfaction Factors to Marital Distress. The Family Journal: Counseling and Therapy for Couples and Families, 9(3), 259-264.

Sabatelli, R.M. (1988). Exploring relationship satisfaction: a social exchange perspective on the interdependence between theory, research and practice. Family Relations, 37(2), 217222.

Saltzman, L. E., Fanslow, J. L., McMahon, P. M., \& Shelley, G. A. (2002). Intimate partner violence surveillance: Uniform definitions and recommended data elements, version 1.0. Atlanta, GA: Centers for Disease Control and Prevention, National Center for Injury Prevention and Control. 
Saraç, A., Hamamcı, Z. \& Güçray, S. (2015). Üniversite Öğrencilerinin Romantik illişki Doyumunu Yordaması. Türk Psikolojik Danışma ve Rehberlik Dergisi, 5(43), 69-81.

Schweitzer, R. D. (1996). Problems and awareness of support services among students at an urban Australian university. Journal of American College Health, 45 (2), 73-77.

Selçuk, E., Gunaydin, G., Sumer, N. \& Uysal A. (2005). Yetişkin bağlanma boyutları için yeni bir ölçüm: Yakın İlişkilerde Yaşantılar Envanteri-II'nin Türk örnekleminde psikometrik açıdan değerlendirilmesi. Türk Psikoloji Yazıları, 8, 1-11.

Shorey, R.C., Cornelius, T.L. \& Bell, K.M. (2008). A critical review of theoretical frameworks for dating violence: Comparing the dating and marital fields. Aggression and Violent Behavior, 13, 185-194.

Simpson, J. A. (1990). The influence of attachment styles on romantic relationships. Journal of Personality and Social Psychology, 59, 971-980.

Steinberg, L. (2007). Ergenlik (F.Çok, Trans.). Ankara: İmge (Original work published 1985).

Stackert, R. A., \& Bursik, K. (2003). Why am I unsatisfied? Adult attachment still, gendered irrational relationships beliefs, and young adult romantic relationship satisfaction. Personality and Individual Differences, 34, 1419-1429.

Stoeber, J. (2012). Dyadic perfectionism in romantic relationships: Predicting relationship satisfaction and long-term commitment. Personality and Individual Differences, 53, 300-305.

Sullivan, B. F., \& Schwebel, A. (1995). The relationships beliefs and expectations of satisfaction in marital relationships. Journal of Family Therapy, 3, 298-306.

Tabachnick, B. G., \& Fidell, L. S. (2007). Using multivariate statistics (5th ed.). Boston, MA: Allyn \& Bacon.

Tjaden, P., \& Thoennes, N. (2000). Extent, Nature, am/ Consequences of Intimate Partner Violence (NCJ 181867). Washington, D.C., U.S. Department of Justice, National Institute of Justice.

Towler, A.J. \& Stuhlmacher,A.F. (2013). Attachment styles, relationship satisfaction, and wellbeing in working women. Journal of Social Psychology, 153, 297-298.

Türkiye'de Kadına Yönelik Aile İçi Şiddet (2009). Public Sector \& Hacettepe Üniversitesi Nüfus Etütleri Enstitüsü \& BNB Consulting, Ankara. http://kadininstatusu.aile.gov.tr/data/542a8e86369dc31550b3ac33/ana_rapor_mizan _1.pdf Accessed in 10 October 2016.

Türkiye İstatistik Kurumu [Turkish Statistical Institute]. (2008). Kadına yönelik aile içi şiddet istatistikleri [Domestic violence against women statistics]. http://www.turkstat.gov.tr/VeriTabanlari.do?ust_id=109\&vt_id=31 accessed in 20.07.2016.

Vefikuluçay D, Zeyneloğlu S, Eroğlu K. \& Taşkın L (2007). Kafkas Üniversitesi son sınıf öğrencilerinin toplumsal cinsiyet rollerine ilişkin bakış açıları. Hemşirelik Yüksekokulu Dergisi, 26-38.

Waters, E., Posada, G., Crowell, J. \& Keng-ling, L. (1993). Is attachment theory ready to contribute to our understanding of disruptive behavior problems? Development \& Psychopathology, 5, 215-224. 
Romantic Relationship Satisfaction Levels of Female University Students in Turkey: Examining through Attachment Dimensions, Perceived Abuse in Relationship and Future Time Orientation of Relationship

Aylin DEMIRLI YILDIZ - Gökçe ÇOKAMAY - Müge ARTAR 


\section{GENiş ÖZET}

Günümüzde $20^{\prime} l i$ yaşların sonuna doğru uzamış olan ve üniversite yıllarını da kapsayan dönem "beliren yetişkinlik denemi" olarak da adlandırılmaktadır. Ergenlik çağının sonrası, yetişkinlik çağının öncülü olan beliren yetişkinlik döneminde özellikle ön plana çıkan gelişim görevlerinden biri romantik ilişkilerde yakınlaşma kapasitesi ve başkalarıyla yakın partner olmaya hazırlanma gibi kişiler arası ilişki becerilerini geliştirmektir. Bu dönemde gençler, yetişkinlik döneminde yaşayacakları romantik ilişkilerin provasını yaparlar. Burada edinilen deneyimler, onların yetişkinlik dönemi romantik ilişkilerinin kalitesini ve uyum düzeyini etkiler (Furman, 2002; Sabetelli, 1988). Beliren yetişkinlik dönemindeki gençler, geçmiş yaşantı ve ilişki deneyimlerinin de etkisi ile romantik ilişkilerini oldukça geniş bir yelpazede deneyimlemektedir. Üstelik bu ilişkilerin kişinin gelişimine etkisi de birbirinden farklıdır. Bazı ilişkiler gelişimi olumlu yönde etkileyip, kişinin sonraki gelişim dönemlerine hazır olmasını ve gelecekte de destekleyici ilişkiler kurabilmesi için gerekli becerileri kazanmasını sağlamaktadır. Öte yandan pek çok ilişki ketleyici ve hatta içerisinde yoğun istismar barındıran bir örüntü izleyebilmektedir. Saltzman, Fanslow, McMahon ve Shelley (2002), romantik ilişkilerde yaşanan istismarı "duygusal birliktelikte eşlerin birbirilerine uyguladıkları fiziksel, cinsel ve duygusal zararlar" olarak açıklamaktadır. Merrell (2001), ise romantik ilişkilerde yaşanan istismarı, "duygusal bir beraberlik yaşayan çiftlerin karşlıklı olarak birbirilerine uyguladıkları veya birinin diğerine uyguladığı psikolojik, fiziksel ve cinsel zorlama yoluyla güç ve kontrol sağlama davranış ve tutumları" olarak tanımlamıştır. Flört dönemindeki istismar uygulanması açısından sözel istismar oranları \%11 ile \%15 arasında değişmekteyken, fiziksel istismar oranları \%9 ile \%43 arasında değişim göstermektedir (Price ve ark., 1999).

Üstelik bu ilişkileri kurmayı başaramayan genç, derin bir yalıtılma duygusu duyabilmektedir. Hem gelecek yönelimi hem güncel yaşantı üzerinde etkili olan romantik ilişkinin kapsadığı alanı ve öncüllerini özellikle beliren yetişkinlik dönemindeki kadınlar açısından araştırmak literatürdeki önemli bir boşluğu dolduracaktır. Bu bağlamda araştırma beliren yetişkinlik döneminin en önemli gelişimsel görevlerinden biri olarak romantik ilişkileri araştırmayı amaçlamaktadır. Bu amaç çerçevesinde araştırmanın temel amacı "Bağlanma boyutları, ilişkide algılanan istismar ve ilişkide gelecek yönelimi ilişki doyumunu yordamakta mıdır?" olarak belirlenmiştir. Diğer yandan araştırmada vakıf üniversitesinde okuyan öğrenciler ile devlet üniversitesi öğrencilerinin ilişkide algıladıkları istismar düzeyi ve ilişkide algıladıkları doyumun düzeyi sınıf, ilişki süresi, gelir durumu, ailelerin eğitim düzeyi ve evlilik durumu gibi değişkenlere açısından farklı olup olmadığı ele alınmıştır.

Bu amaca uygun olarak çalışmalar iki ayrı üniversitede eş zamanlı olarak gerçekleştirilmiştir. 2013-2014 eğitim yılında Başkent Üniversitesi Eğitim Fakültesi ve Ankara Üniversitesi Eğitim Bilimleri Fakültesinde eş zamanlı olarak gönüllü öğrencilerin katııımı ile 410 kadın öğrenciden veri toplanmışıır. Katılımcıların 257'si (\%62.7) Ankara Üniversitesi'nden 153'ü (\%37.3) Başkent Üniversitesi öğrencisidir. Katılımcıların yaş ortalaması 23'tür. Katıımcılardan 29'unun (\%7.1) 1 aydan daha kısa süreli ilişkisi vardır. 35 katıımcı(\%8.5) 1 ile 3 ay arası ilişkiye sahip olduğunu ifade etmiştir. 41 katıımcı (\%10.0) 3 ile 6 ay arası ilişkiye sahip iken, 58 (\%14.1) 6 ay ile 1 yıl arası devam eden bir ilişkiyi devam ettirmektedir. 93 (\%22.7) katıımonının 2 ile 4 yıl arası ilişkisi varken 42 araştırmacı 4 ile 6 yıldır devam eden bir ilişkisi olduğunu ifade etmiştir. 31 katılımcı (\%7.6) ise 6 yıldan daha uzun süredir devam eden bir romantik ilişkiye sahiptir.

Araşıırıada kullanılan veri toplama araçları Demografik Bilgi Formu, Romantik ilişki Doyum Ölçeği, Romantik ilişkilerde Gelecek Yönelimi Ölçeği, Yakın İlişki Yaşantıları Envanteri ve Romantik iliş̧iyi Değerlendirme Ölçeği'dir. Araştırma verileri, araştırmacılar tarafından, gönüllü öğrencilere ders saatlerinde uygulanmıştır. Uygulama esnasında katıımcılara araştırmacıların kimlik ve iletişim bilgileri verilmiştir.

Araştırma amaçlarına uygun olarak öncelikle katılımcıların demografik özelliklerinin ilişki doyumu ile ilişkisi varyans analizleri kullanılarak incelenmiştir. Ardından hiyerarşik regresyon analizinin gerektirdiği varsayımların karşılanıp karşılanmadığı incelenmiştir. Hiyerarşik regresyon analizinde bağımlı değişkenle çok sayıda bağımsı değişkenin arasındaki yordama ilişkisi incelenmektedir. Bağımsız değişkenler regresyon denklemine ayrı bloklar halinde dahil edilmekte; böylelikle her birinin bağımlı değişken ile ilişkisinin diğerlerinden ayrı olarak da ele alınması amaçlanmaktadır. 
Araştırma sonuçları vakıf üniversitesi öğrencilerinin romantik ilişkilerinde daha fazla doyum yaşadıklarını ortaya koymuştur. Dahası, üst sınıf öğrencileri ve daha uzun süreli ilişki sahibi olanların ilişki doyumu daha yüksek bulunmuştur.

Son olarak regresyon analizi sonuçlarına göre romantik ilişki doyumunun sırası ile kaçınan bağlanma, romantik ilişkilerde algılanan istismar, kaygılı bağlanma ve ilişkide gelecek yönelimi ile ilişkili olduğu bulunmuştur. Tüm model bütün olarak ele alındığında kaçınan ve kaygılı bağlanma boyutları, ilişkide algılanan istismar ve ilişkide gelecek yönelimi beta değerleri sırasıyla $B=-.27, p<.01 ; B=-.23, p<$ $.01 ; B=-.23, p<.01 ;$ ve $B=.15, p<.01$ olarak bulunmuştur. Kaçınan bağlanma boyutu ilişki doyumunu tek başına orta düzeyde anlamlı olarak yordamıştır $\left(R^{2}=.19 \Delta \mathrm{R}^{2}=.19, F(1,408)=95.37, p=.00\right)$. Kaygılı bağlanma boyutunun eklenmesi ile birlikte ilişki doyumu $R^{2}=.25, \Delta \mathrm{R}^{2}=.24, F(1,407)=31.66, p=.01$ anlamlı olarak yordanmıştır. Son olarak ilişkide algılanan istismar eklendiğinde $R^{2}=.30, \Delta \mathrm{R}^{2}=.30, F(1$, $406)=30.63, p=.01$ olmuştur. Sonuç olarak modelin tümü ele alındığında tüm değişkenler bir arada ilişki doyumunun \%32'sini açıklamaktadır. Bağımsız değişkenlerin hangisinin varyansı açıklamada daha yüksek düzeyde anlamlı olduğuna bakıldığında en güçlü kısmi değişkenin kaçınan bağlanma boyutu ile ilişki doyumu arasında $.43(p=.00)$ olduğu görülmektedir. 